\title{
The Effect of Regional Characteristics on Type of Crime and Crime Report Calls
}

\author{
Hyun Soo Kim \\ Department of Security Management, Kyonggi University \\ Suwon, Republic of Korea \\ Julak Lee (Corresponding author) \\ Associate Professor, Department of Security Management, Kyonggi University \\ Suwon, Republic of Korea \\ E-mail: julaklee@kgu.ac.kr
}

Received: July 10, 2017 Accepted: August 2, 2017 Published: September 20, 2017

doi:10.5296/ijssr.v5i2.11880 URL: http://dx.doi.org/10.5296/ijssr.v5i2.11880

\begin{abstract}
Given a sample of criminal activities in South Korea, the following assessment focuses on 112 reports requesting government assistance concentrated in certain area at a specific time. Analysis of the aforementioned incident reports highlight the strategic placement of police patrols in crime vulnerable areas where they are reported play a critical role towards crime prevention. As such, this study analyzed the regional characteristics of each district based on metrics provided by the National Police Agency. Regression analysis performed on this hypothesis yielded the following results. First - analyzing the effects of regional characteristics regarding major crimes and other crimes - the regional characteristics of lodging facilities, educational institutions, financial institutions, public facilities, karaoke bars, and foreign residents showed a positive effect. Second - as a consequence of analyzing the effects of regional characteristics on report code considering the urgency level of the incidents - the regional characteristics of lodging facilities, entertainment pubs, educational institutions, financial institutions, public facilities, and foreign residents showed a positive effect. Lastly, this study analyzed the connection between 112 report codes with crime types, in addition their causal effects, proved to be significant.
\end{abstract}

Keywords: Regional characteristics, type of crime, hotspot, 112 crime report call, crime prevention 


\section{Introduction}

Korean National Police Agency have decided that the existing police system would be difficult to provide security services suitable for regional circumstances as a means for innovation in order to achieve the effective 112 calls for service. Thus, as of August 1, 2003, a major change was made in the police activities focused on traditional police stations and to pursue dynamic local police activities. So that local police system was implemented in which all the police stations in the country were reorganized into police patrol division.

The local police system is evaluated as one of the police innovation measures to make the operation of the police stations closest to the people, so that people who need security services can live a safe and comfortable life. In order for integrating three to five police substations, the National Police Agency intensively worked on the personnel and equipment of the police stations to operate police patrol division to deal effectively with crime by taking into account the local situation such as population, area, resident's life zone, transportation network, etc. Therefore, 112 calls for service has been expanded to provide public services to local residents, thereby reducing the fear of crime.

However, since it is difficult to respond adequately to rapidly growing number of calls for service that caused by limited police force, Korean National Police Agency established a plan of "Efficiency of Local Police Patrols at Base". Also through the Geo-pros (geographic profiling systems), the Police Agency has been operating by securing and placing patrols to analyze crime Hotspot. Even in the case of the United States, there are many efforts to reduce the emergency calls (911) and many studies shows that the emergency calls don't occur evenly in all areas, but occurs in specific areas.

Also in case of South Korea, it has shown that 112 calls for service is concentrated in certain areas in specific time. Therefore, placing police patrols in crime vulnerable areas where the report are being concentrated, are very important in terms of crime prevention. However, the standards of placing police force are based on past material. Naturally, analyzing the current trend based on past material can be feasible and rational. The development of new cities in South Korea has been conducted and there are many places that are newly built. In the case of such areas, it can be difficult to analyze with past data because of the lack of validity and reliability. In addition, predictive policing requires a comprehensive and multilateral material.

Therefore, this study analyzes the regional characteristics of each region based on the data of the National Police Agency because it shows different forms and results followed by 112 calls for service reports. Also, it will derive the necessary data or information for prevention of crime and preparations of measures.

\section{Theoretical Background}

\subsection{Reporting System}

The 112 police reporting system in Korea began in 1957 with the support of the Ministry of Communications. The 112 report system was introduced for the first time by starting with the installation in the city of Busan and Seoul (Lee, 2012). Since the system of 112 patrol 
vehicles has been settled, the police service system has been established to provide an emergency response reporting system based on the concept of C3 (command, control, communication) so that it can respond to citizen's demands promptly (Kang \& Choi, 2013).

In order to cope effectively with various situations including the 112 report, the police set up a 24-hour 112 emergency dispatch center in each police station and follow the guideline of "Operation of 112 Emergency Dispatch Center and Report Handling Rules" of the Police Agency. When the 112 emergency dispatch center received the report, the agent will start to analyze what the report is about. The police patrols will be dispatched at the scene and the on-site response and situation report are done (Korea National Police Agency, 2016).

The victim or witness' report is the first step of the 112 report. Based on the subjective judgment of the reporter, it is possible to report if the police force is necessary. In this case, location based service (LBS) is used to accurately identify the position of the reporter (Kang \& Choi, 2013).

When the victim's report is connected to the 112 emergency dispatch center, the police officer asks the information related to the incident, such as the location of the reporter, the perpetrator's information, and the damage situation. There are many cases in which the reporter is a victim or an incident-related person. When the report is filed, mental fear or an urgent situation often interrupt for accurate communication between the reporter and the agent. In this case, the police agent needs know-how to deal with the communication. Depending on the situation, the police officer should be able to listen to the report by using the internal emergency hearing system so that the officer can hear it in real time while working in the field (Lee, 2012).

When the report is received, the emergency operations room analyzes the contents of the report, judges the appropriate police action according to the situation, and places the police forces on the scene of the incident. Typically, a police officer in the vicinity of the crime scene is commanded, and specific and precise orders greatly affect the success or failure of the first action.

According to Article 13 of Regulations for Reporting Policies, differential police response is specified as follows. The police officer at the 112 emergency dispatch center classifies the report with code 1, 2, and 3 considering the urgency of the incident and the need for dispatch.

The code 1 is the case that the priority dispatch is necessary for the protection of persons and property, the elimination and prevention of serious public risks. The code 2 is a case that a police dispatch is necessary, but it is not a part of the code 1 . The code 3 report is a case where on-site action is not required.

Therefore, in case of codes 1 and 2, the police are dispatched, but in case of code 3 , the police are not dispatched and only provide verbal guidelines.

\subsection{Police Activity in Hotspot}

Exploring crime hotspot is crucial in crime prevention. It directly helps police patrol activity (Hough \& Tilley, 1998; Goldsmith et al., 2000; Osborne \& Wernicke, 2003) and is useful for 
analyzing crime patterns Chainey \&Ratcliffe, 2005). It is also used in performance analysis of crime prevention (Walsh, 2001; Schick, 2004).

Crime does not occur evenly throughout the police jurisdiction, but it occurs intensively around certain areas called hotspots (Sherman \& Weisburd, 1995). Crime is also closely related to the nature of the place. Criminals commit crimes in their homes, workplaces, bars, or clubs (Brantingham \& Brantingham, 1981; Chainey \& Ratcliffe, 2005). Lim (2005) studied the relationship between crime and local characteristics in Gangnam police station and he found out that theft and robbery cases occurred mainly in dense areas of small houses, while violent crimes occurred intensely near bars and clubs.

Lee and Cho (2006) analyzed crimes in 31 places of Seoul. They confirmed that the number of floating population and the number of bars and clubs within police jurisdiction have positive correlation with violent crime. In other words, the more the number of floating population or the more the number of bars and clubs are located within the jurisdiction of the police station, the more violent crime has occurred. In addition, social structural variables such as divorce rate, foreigner rate and economic disadvantage in the police jurisdiction affected crime occurrence (Jung \& Kwak, 2007). These studies suggest that police should not only conduct police activities focusing on criminals or victims, but also actively conduct place-based policing that develop police activities around crime vulnerable areas (Kang \& Kwak, 2008).

\section{Research Method}

\subsection{Research Subjects}

The data used in the study are based on the number of 112 report calls of 2013 filed at police stations or police substations of 1,124 jurisdictional areas throughout the country. The descriptive statistics of National 112 Report Profile Database is shown in Table 1.

Table 1. Descriptive statistics

\begin{tabular}{ccc}
\hline Variables & Average Per a Police Station & Total \\
\hline Major Crime & 315.08 & 346,593 \\
Other Crime & 1874.70 & $2,062,175$ \\
\hline Report Code 1 & 1016.90 & $1,135,873$ \\
Report Code 2 & 3434.11 & $3,835,902$ \\
\hline Lodging Facility & 45.67 & 35,988 \\
Entertainment Pub & 50.63 & 46,930 \\
Karaoke Bar & 26.67 & 25,418 \\
Education Institution & 14.25 & 16,006 \\
Financial Institution & 25.85 & 29,032 \\
Public Facility & 153.76 & 172,678 \\
Large Cash Handling Facility & 69.39 & 77,922 \\
Foreign Residents & 1727.11 & $1,725,378$ \\
Public Park & 18.47 & 19,244 \\
\hline
\end{tabular}




\subsection{Operational Definition of Variables}

\subsubsection{Regional Characteristics}

In the study of Kang and Choi (2015), police station, resident population within police jurisdiction, lodging facilities, educational institutions, cash handling facilities, the number of foreign residents, and etc. were established as regional characteristics and examined the relationship with 112 report calls.

In order to achieve the purpose of this study, the factors of regional characteristics were extracted referring to routine activity theory of Cohen and Felson (1979), The characteristics of crime hotspots were identified by Eck et al. (2005), and Kang and Choi (2015).

In addition to the statistics of the National Korean Police Agency(2015), the areas where the reports were received were largely divided into lodging facilities, entertainment pub, karaoke bar, education institution, financial institution, public facility, large cash handling facility, foreign resident, and public park.

\subsubsection{Types of Crime}

The 2011 Crime Statistics published by the National Police Agency classified crime types based on Violation Attributes and Type of Legal Interest Infringement. The classified crime types are violent crime, theft crime, intelligent crime, customary crime, economic crime, drug crime, health crime, traffic crime, environmental crime, labor crime, security crime, electoral crime, military crime, and other crime. In order to achieve the purpose of this study, this study largely divided the crime types into major crime and other crime.

\subsubsection{Report Calls}

As described above, all report calls are divided into code 1,2, and 3. The code 3 is excluded from this study because it is not related to the police or does not require dispatch.

Therefore, the analysis targets are report code 1 (the priority dispatch is necessary for the protection of persons and property, the elimination and prevention of serious public risks) and report code 2 (police dispatch is necessary, but not as serious as code 1).

\subsection{Research Model}

The purpose of this study is to identify the derived factors of hotspot's characteristics that affect 112 report calls. After confirming the relationship between the regional characteristics and 112 report calls, it will be important to be able to manage the regional characteristics that affect the 112 report calls. The ultimate goal is to reduce local crime and strengthen safety management.

In order to achieve the purpose of this study, a research model was designed as shown in Figure 1. 


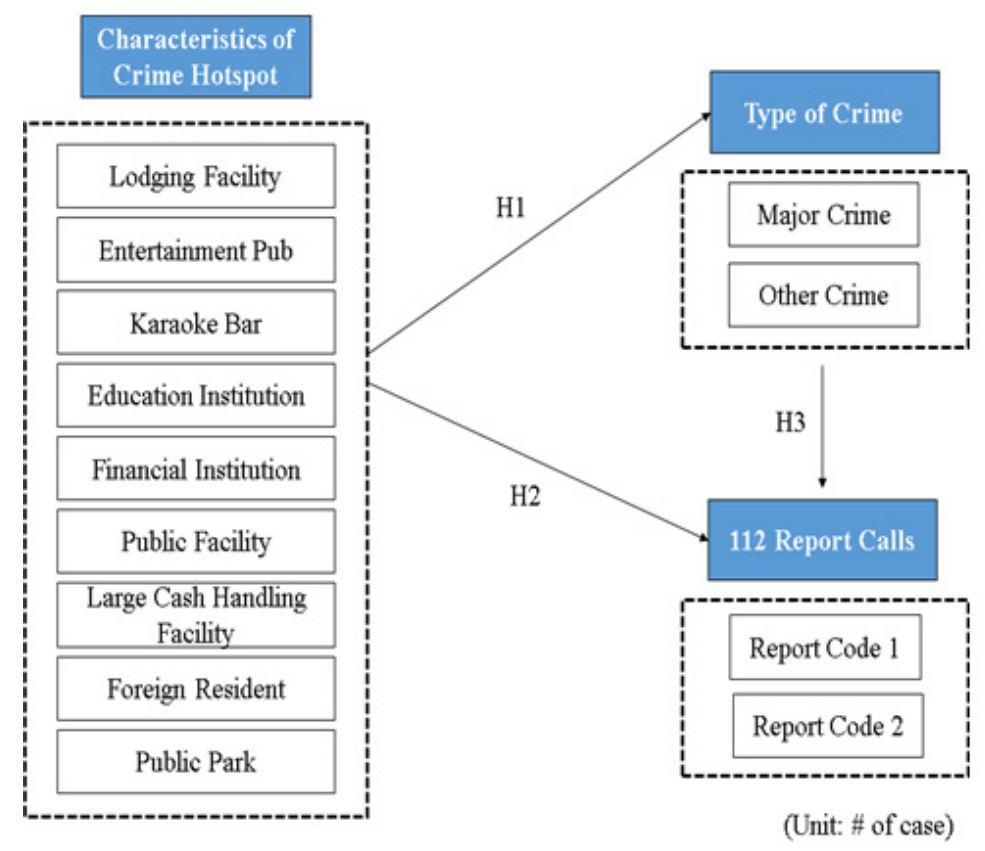

Figure 1. Research model

\subsection{Hypotheses}

Based on the purpose of this study as shown through the research model, hypotheses were established based on the regional characteristics, the types of crime, and the types of 112 report calls.

The detailed factors of the regional characteristics were selected as lodging facilities, entertainment pub, karaoke bar, education institution, financial institution, public facility, large cash handling facility, foreign resident, and public park. 112 report calls were classified into code 1 and code 2 according to the importance of reported cases. Finally, the types of crime are classified into major crime and other crime.

Therefore, this study set the following hypotheses to verify whether the regional characteristics, the number of 112 reports, and the types of crime are related to each other. The hypotheses are as follows.

H1 : The regional characteristics will have a significant impact on the types of crime.

H2 : The regional characteristics will have a significant impact on the 112 report calls.

H3 : The type of crime will have a significant impact on the number of 112 report calls.

There are many studies on the relationship about regional characteristics, types of crime and 112 report calls such as Triplett et al.(2003), Sampson and Groves(1989), and Jeong(2006) Kang and Choi(2015), Yim(2006), and Cha et al.(2015). In addition, the related theories described in the theoretical background were also used for setting up the hypotheses in above.

As a method of analysis, regression analysis was performed to analyze the relationship between each factor according to research model, using SPSS Ver.24.0 statistical package. 


\section{Result of Analysis}

\subsection{Effects of Regional Characteristics on Major Crimes}

Table 2 is the result of analyzing the effects of regional characteristics on major crimes. By looking at each factors, the regional characteristics of lodging facilities, education institutions, financial institutions, and foreign residents showed a positive effect on major crimes at the $\mathrm{p}<0.05$ level. In other words, the more the number of lodging facilities, educations institutions, financial institutions and foreign residents there are in the area, the more major crimes occurred.

This indicates that the more lodging facilities there are in the area, the more major crimes occurred. Education institutions with many youngsters were also exposed to major crimes. In addition, there were many major crimes occurred in area with financial institutions where money transactions are made from time to time. The number of foreign residents was also exposed to major crimes.

Table 2. Effects of regional characteristics on major crimes

\begin{tabular}{|c|c|c|c|c|c|}
\hline & \multicolumn{2}{|c|}{$\begin{array}{l}\text { Unstandardized } \\
\text { Coefficients }\end{array}$} & \multirow{2}{*}{$\begin{array}{c}\begin{array}{c}\text { Standardized } \\
\text { Coefficients }\end{array} \\
\text { Beta }\end{array}$} & \multirow[t]{2}{*}{$\mathrm{t}$} & \multirow[t]{2}{*}{ Sig. } \\
\hline & $\mathrm{B}$ & Std. Error & & & \\
\hline (Constant) & 39.949 & 17.331 & & 2.305 & .022 \\
\hline Lodging Facility & 1.148 & .366 & .136 & 3.134 & .002 \\
\hline Entertainment Pub & .197 & .234 & .037 & .842 & .400 \\
\hline Karaoke Bar & -.084 & .454 & -.008 & -.185 & .854 \\
\hline Education Institution & 14.430 & 2.143 & .303 & 6.732 & .000 \\
\hline Financial Institution & 8.408 & 1.029 & .354 & 8.171 & .000 \\
\hline Public Facility & -.038 & .073 & -.019 & -.525 & .600 \\
\hline Large Cash Handling Facility & .039 & .130 & .010 & .298 & .766 \\
\hline Foreign Residents & .017 & .005 & .110 & 3.233 & .001 \\
\hline Public Park & 1.303 & 1.229 & .046 & 1.061 & .289 \\
\hline
\end{tabular}

\subsection{Effects of Regional Characteristics on Other Crimes}

Table 3 is the effect analysis of regional characteristic on other crimes. The regional characteristics of karaoke bars, financial institutions, public facilities, foreign residents showed a positive effect on other crimes at the $p<0.05$ level. Especially, the most other crimes occurred in areas of educational institutions and foreign residential area and followed by karaoke bars and public facilities.

Unlike the factors affecting the major crime above, it was found that the karaoke bars had a 
significant influence on other crimes. Karaoke bar is a place to sell liquor by hiring hostesses in accordance with legal permission from amusement business. Since the karaoke bars is hostess related business, it shows that other crimes occurred more frequently than major crimes.

Financial institutions have a significant impact on other crimes as well as major crimes above. Other crimes also occurred in areas with financial institutions such as banks, post offices, and etc.

In addition, 112 report calls related to other crimes were received at public facilities such as bus stations, subway stations, bus terminals, train stations, and etc. where many people were concentrated. The number of foreign residents was also exposed to other crimes.

Table 3. Effects of regional characteristics on other crimes

\begin{tabular}{|c|c|c|c|c|c|}
\hline & \multicolumn{2}{|c|}{$\begin{array}{l}\text { Unstandardized } \\
\text { Coefficients }\end{array}$} & \multirow{2}{*}{$\begin{array}{c}\text { Standardized } \\
\text { Coefficients }\end{array}$} & \multirow[t]{2}{*}{$\mathrm{t}$} & \multirow[t]{2}{*}{ Sig. } \\
\hline & $\mathrm{B}$ & Std. Error & & & \\
\hline (Constant) & 423.420 & 145.441 & & 2.911 & .004 \\
\hline Lodging Facility & 5.155 & 3.075 & .079 & 1.676 & .094 \\
\hline Entertainment Pub & -3.530 & 1.964 & -.086 & -1.797 & .073 \\
\hline Karaoke Bar & 11.856 & 3.811 & .148 & 3.111 & .002 \\
\hline Education Institution & 27.099 & 17.987 & .073 & 1.507 & .133 \\
\hline Financial Institution & 67.755 & 8.635 & .367 & 7.846 & .000 \\
\hline Public Facility & 1.307 & .612 & .082 & 2.135 & .033 \\
\hline Large Cash Handling Facility & 1.661 & 1.089 & .058 & 1.525 & .128 \\
\hline Foreign Residents & .251 & .043 & .215 & 5.837 & .000 \\
\hline \multirow[t]{2}{*}{ Public Park } & -6.085 & 10.315 & -.028 & -.590 & .556 \\
\hline & & & & & $\mathrm{p}<.05$ \\
\hline
\end{tabular}

\subsection{Effects of Regional Characteristics on Report Code 1}

Table 4 is the consequence of analyzing the effects of regional characteristics on report code 1. According to the analysis results, the regional characteristics of entertainment pubs, financial institutions, public facilities, and foreign residents showed a positive effect on report code 1 at the $p<0.05$ level. In other words, the more the number of entertainment pubs, financial institutions, public facilities and foreign residents there are in the area, the more 112 report code 1 were received. 
As described above, Code 1 is the case that the priority dispatch is necessary for the protection of persons and property, the elimination and prevention of serious public risks. The analysis results seem to be heavily exposed to serious public dangers where protection of persons and property is needed in the above areas.

Table 4. Effects of regional characteristics on report Code 1

\begin{tabular}{|c|c|c|c|c|c|}
\hline & \multicolumn{2}{|c|}{$\begin{array}{l}\text { Unstandardized } \\
\text { Coefficients }\end{array}$} & \multirow{2}{*}{$\begin{array}{c}\text { Standardized } \\
\text { Coefficients }\end{array}$} & \multirow[t]{2}{*}{$\mathrm{t}$} & \multirow[t]{2}{*}{ Sig. } \\
\hline & $\mathrm{B}$ & Std. Error & & & \\
\hline (Constant) & 239.199 & 85.015 & & 2.814 & .005 \\
\hline Lodging Facility & 3.444 & 1.842 & .086 & 1.869 & .062 \\
\hline Entertainment Pub & -4.178 & 1.162 & -.168 & -3.596 & .000 \\
\hline Karaoke Bar & 3.584 & 2.293 & .073 & 1.563 & .119 \\
\hline Education Institution & 7.690 & 10.774 & .035 & .714 & .476 \\
\hline Financial Institution & 45.909 & 5.106 & .423 & 8.991 & .000 \\
\hline Public Facility & -.792 & .304 & -.099 & -2.609 & .009 \\
\hline Large Cash Handling Facility & 1.050 & .657 & .060 & 1.599 & .110 \\
\hline Foreign Residents & .186 & .026 & .262 & 7.181 & .000 \\
\hline \multirow[t]{2}{*}{ Public Park } & 3.517 & 6.038 & .027 & .582 & .560 \\
\hline & & & & & $* \mathrm{p}<.05$ \\
\hline
\end{tabular}

\subsection{Effects of Regional Characteristics on Report Code 2}

Following the effects of regional characteristics on report code 1, Table 5 is the effects of regional characteristics on report code 2. According to the analysis results, the regional characteristics of lodging facilities, educational institutions, financial institutions, public facilities, and the number of foreign residents showed a positive effect on report code 2 at the $\mathrm{p}<0.05$ level. In other words, the more the number of lodging facilities, educational institutions, financial institutions, public facilities, and foreign residents there are in the area, the more 112 report code 2 were received.

This indicates that financial institutions have a significant impact on the number of report code 2 . In other words, 112 report calls were being made as code 2 in areas with financial institutions such as banks, post offices, and etc. 
Table 5. Effects of regional characteristics on report Code 2

\begin{tabular}{|c|c|c|c|c|c|}
\hline & \multicolumn{2}{|c|}{$\begin{array}{l}\text { Unstandardized } \\
\text { Coefficients }\end{array}$} & \multirow{2}{*}{$\begin{array}{c}\begin{array}{c}\text { Standardized } \\
\text { Coefficients }\end{array} \\
\text { Beta }\end{array}$} & \multirow[t]{2}{*}{$\mathrm{t}$} & \multirow[t]{2}{*}{ Sig. } \\
\hline & B & Std. Error & & & \\
\hline (Constant) & 614.021 & 176.446 & & 3.480 & .001 \\
\hline Lodging Facility & 14.540 & 3.824 & .156 & 3.803 & .000 \\
\hline Entertainment Pub & 2.718 & 2.411 & .047 & 1.127 & .260 \\
\hline Karaoke Bar & 5.079 & 4.759 & .045 & 1.067 & .286 \\
\hline Education Institution & 91.452 & 22.360 & .177 & 4.090 & .000 \\
\hline Financial Institution & 103.013 & 10.597 & .409 & 9.721 & .000 \\
\hline Public Facility & 1.389 & .630 & .075 & 2.204 & .028 \\
\hline Large Cash Handling Facility & 1.639 & 1.363 & .040 & 1.202 & .230 \\
\hline Foreign Residents & .199 & .054 & .120 & 3.695 & .000 \\
\hline Public Park & 5.462 & 12.531 & .018 & .436 & .663 \\
\hline
\end{tabular}

\subsection{Effects of Crime Types on Report Code 1}

Table 6 is the effects of crime types on report code 1 . According to the analysis results, the major crimes and other crimes showed a positive effect on report code 1 at the $p<0.05$ level. In other words, the more the number of major crimes and other crimes there are in the area, the more 112 report code 1 were received. The p-value for major crime is .003 and the p-value of other crime is .000 . It means that other crime is more significant than the major crime.

As the day goes by, crimes evolve and new types of crime occur(Korea National Police Agency, 2016). If new types of crime are filed to 112 emergency center, it seems to be that the systematic countermeasures are not provided according to the new types of crime. Judging by variety of circumstances, other crimes are filed as code 1 in many cases.

Table 6. Effects of crime types on report Code 1

\begin{tabular}{cccccccc}
\hline & \multicolumn{2}{c}{ Unstandardized Coefficients } & & \multicolumn{2}{c}{ Standardized Coefficients } & \multirow{2}{*}{ Sig. } \\
\cline { 2 - 3 } & $\mathrm{B}$ & Std. Error & & Beta & & \\
\hline (Constant) & 102.072 & 26.533 & & & 3.847 & .000 \\
Major Crime & .293 & .098 & & .078 & 2.978 & .003 \\
Other Crime & .448 & .015 & & .772 & 29.436 & .000 \\
\hline
\end{tabular}




\subsection{Effects of Crime Types on Report Code 2}

Following the effects of crime types on report code1, Table 7 is the effects of crime types on report code 2 were analyzed. The major crimes and other crimes showed a positive effect on report code 2 at the $p<0.05$ level. In other words, the more the number of major crimes and other crimes there are in the area, the more 112 report code 2 were received.

The p-value for major crimes and other crimes are equally 0.000 . It means that the both major crimes and other crimes have a significant impact on report code 2.

Table 7. Effects of crime types on report Code 2

\begin{tabular}{|c|c|c|c|c|c|}
\hline & \multicolumn{2}{|c|}{ Unstandardized Coefficients } & \multirow{2}{*}{$\frac{\text { Standardized Coefficients }}{\text { Beta }}$} & \multirow{2}{*}{$\mathrm{t}$} & \multirow{2}{*}{ Sig. } \\
\hline & B & Std. Error & & & \\
\hline (Constant) & 458.848 & 49.674 & & 9.237 & .000 \\
\hline Major Crime & 4.933 & .184 & .489 & 26.754 & .000 \\
\hline \multirow[t]{2}{*}{ Other Crime } & .766 & .028 & .492 & 26.921 & .000 \\
\hline & & & & & $* \mathrm{p}<.05$ \\
\hline
\end{tabular}

\section{Conclusion and Policy Implication}

This study examined the effects of regional characteristics on crime types and 112 report calls. The study also examined the relationship between crime types and 112 reports. The ultimate goal was to reduce crime rates and strengthen safety management in the region through the data derived from this study. Most of the factors have significant influence on each other.

As the result of analyzing the effects of regional characteristics on major crime and other crime, The area of financial institutions and the school district were analyzed as having a high number of major crime and other crime. An unusual particular from this result is that the entertainment pub and the karaoke bars showed a negative effect on the major crimes. It can be predicted that the area with the entertainment pubs and the karaoke bars have more investment on police force in preparation for major crimes than in other areas.

As the consequence of analyzing the effects of regional characteristics on report code 1 and 2, the regional characteristics of financial institutions, public facilities, and foreign residents were analyzed as having a high number of report code 1 and 2 . As in the case of the above major crime, regional characteristics' factors of the entertainment pub and the karaoke bars showed a negative effect on the report code 2. As described above, police activities are concentrated in these places and minor cases can be seen as being effectively enforced. Therefore, the rate of reports being classified as code 2 is lower than code 1 .

In addition, after the result of the analysis of nine factors affecting the number of crime types and 112 reports, the number of foreign residents has significant impact on the number of 
major crime, other crime, and the report code 1 and 2. In other words, the more number of foreign residents in the area, the more number of crimes are reported to police. Currently, foreign criminals continue to increase and foreigners related crime rates are also increasing. For the countermeasures against this, voluntary crime prevention guards and multi-cultural family centers have been established. However, a more proactive effort should be made to prevent crime.

Lastly, this study analyzed the relationship between 112 report codes and crime types and these influence relationships were found to be significant. In other words, the more the number of major crimes and other crimes there are in the area, the more 112 report code 1 and code 2 were received. Specifically, both major crime and other crime showed a positive effect on code 1, but other crimes showed little more positive effect than major crime. Other crimes are literally crimes that are not included with major crimes. As day goes by, crimes evolve and new types of crime occur (Korea National Police Agency, 2016). The researcher assumed that if new types of crime are filed to 112 emergency center, the systematic countermeasures are not fully provided according to the new types of crime. Judging by variety of circumstances, other crimes are filed as code 1 in many cases.

Also, the researcher thought that other crime would affect code 2 more than code 1 . However, both major crime and other crime factors showed a significant probability of 0.00 value. According to Article 13 of Regulations for Reporting Policies, 112 report code 2 is a case that only an on-site action and dispatch of police are required, but it is not as serious as code 1 . Judging by these results, the idea of other crime being reported as code 2 was just a baseless guess because there are many types of various situations in accidents or incidents, major crime and other crime appeared to be filed with report code 2 . Generally speaking, classifying the report code 1 and 2 as major crime and other crime can be a natural result. The researcher carried out a confirmatory verification of whether this general idea is correct. The analysis result proved that code 1 and 2 showed positive impact on the major crime and other crime and vice versa.

It is significant that this study analyzed the regional characteristics into nine different factors of lodging facility, entertainment pub, karaoke pub, educational institutions, public facility, large cash handling facility, foreign residents, and public parks. However, there is a limit to the fact that one of the most important elements in the crime hotspots, general pubs and illegal entertainment places, are not subdivided. It is necessary to conduct in-depth interviews with police officers and illegal business owners in order to identify these factors. In the case of illegal businesses, the owners or the customers are often afraid to report crime because they are afraid of punishment. In the follow-up study, the research will be proceeded with the above factors.

\section{References}

Brantingham, P. J., \& Brantingham, P. L. (1981). Environmental Criminology. Beverly Hills. CA: Sage.

Cha, K. H. Kim, K. H. Son, K. J. Kim, S. J. Lee, D. C., \& Kim J. Y. (2015). Analysis of 
Relation Between Criminal Types and Spatial Characteristics in Urban Areas. Korea Society of Satellite Technology.

Chainey, S. P., \& Ratcliffe, J. H. (2005). GIS and Crime Mapping. London: Wiley.

Cohen, L. E., \& Felson, M. (1979). Social Change and Crime Rate Trends: A Routine Activity Approach. American Sociological Review, 44(4), 588-608.

Eck, John E., Chainey, Spencer, Cameron, James G., Leitner, Michael \& Wilson, Ronald E. (2005). Mapping Crime: Understanding Hot Spots. Washington, DC: National Institute of Justice.

Goldsmith, V., McGuire, P. G., Mollenkopf, J. H., \& Ross, T. A. (2000). Analysing Crime Patterns: Frontiers of Practice. New York: Altamira Press.

Hough, M., \& Tilley, N. (1998). Getting the Grease to the Squeak: Research Lessons for Crime Prevention. Crime Prevention and Detection Paper. London: Home Office.

Jeong, S. M. (2006). A Study on the Effects of Community Characteristics and Police Activities on Crimes. PhD. Dissertation. Keimyung University.

Jung, J. S., \& Kwak, D. H. (2007). A Study on the Effects of Community Conditions on Crime Rates: Longitudinal Analyses Using the Growth Curve Model. Winning Papers of 2005 Graduate Paper Competition. Statistics Korea, 136-181.

Kang, W., \& Choi, C. G. (2013). Factors Affecting Citizen Satisfaction in Reporting 112. Korean Public Administration Review, 47(4), 73-91.

Kang, W., \& Kwak D. H. (2008). Place-Based Policing and Policy Implications. Police Journal, 8(2), 61-87.

Korea National Police Agency. (2016). White Paper on Police. The National Police Agency.

Lee, J. W. (2012). Comparative Studies with the Police Response to 911 Calls in the U.S. MA. Thesis. Korea University.

Lee, S. W., \& Cho, J. G. (2006). The Effects of Spatial and Environmental Factors on Crime Victimization. Seoul City Research. 57-76.

Lim. (2005). A Study on Community-based Crime Prevention. Korean Journal of Public Safety and Criminal Justice, 19, 1-31.

National Korean Police Agency. (2015). Operation of 112 emergency Dispatch Center and Report Handling Rules. The National Police Agency.

Osborne, D. A., \& Wernicke, S. C. (2003). Introduction to Crime Analysis: Basic Resources for Criminal Justice Practice. New York: Haworth Press.

Sampson, R., \& Groves, W. (1989). Community Structure and Crime: Testing Social Disorganization Theory. The American Journal of Sociology, 94(4), 774-802.

Schick, W. (2004). Comp Stat in the Los Angeles Police Department. Police Chief, 71(1), 
$17-23$.

Sherman, L. W., \& Weisburd, D. (1995). General Deterrent Effects of Police Patrol in Crime 'Hot spots': A Randomized, Controlled Trial. Justice Quarterly, 12(4), 626-648.

Triplett, R. A. Gainey, R. R., \& Sun, I. Y. (2003). Institutional Strength, Social Control and Neighborhood Crime Rates. Theoretical Criminology, 7, 439-467.

Walsh, W. (2001). Comp stat: An Analysis of an Emerging Police Paradigm. An International Journal of Police Strategies and Management, 24(3), 347-363.

Yim, Y. M. (2006). A Study on the 112 System of the Police. MA. Thesis. Hansei University.

\section{Copyright Disclaimer}

Copyright for this article is retained by the author(s), with first publication rights granted to the journal.

This is an open-access article distributed under the terms and conditions of the Creative Commons Attribution license (http://creativecommons.org/licenses/by/3.0/). 